\title{
VISUALIZING PARABOLA: THE STUDY OF A MANIPULATIVE'S EFFECTIVENESS
}

\author{
Eyus Sudihartinih $^{1}$, Tia Purniati ${ }^{2}$ \\ ${ }^{1}$ Universitas Pendidikan Indonesia, Indonesia, eyuss84@upi.edu \\ ${ }^{2}$ Universitas Pendidikan Indonesia, Indonesia, tiapurniati@upi.edu
}

\section{ARTICLE INFORMATION}

Received: November 30, 2019

Revised: December 28, 2019

Available online: December 31, 2019

\section{KEYWORDS}

Analytic geometry, manipulatives, quasi-experiment, parabola, conics

CORRESPONDENCE

EYUS SUDIHARTINIH

E-mail: eyuss84@upi.edu

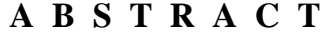

Terdapat alat peraga untuk membantu siswa dalam belajar matematika untuk memvisualisasikan konsep parabola. Artikel ini akan menunjukkan bagaimana mahasiswa menggunakan alat peraga dalam kelas geometri analitik, dan melaporkan hasil dari keefektifan penggunaan alat peraga. Partisipan yang dibagi pada dua kelas, yaitu kelas eksperimen yang perkuliahannya dengan alat peraga, dan kelas kontrol tanpa menggunakan alat peraga. Instrumen yang digunakan yaitu tes, wawancara, dan angket. Hasil analisis data menunjukkan bahwa siswa yang menggunakan alat peraga lebih baik daripada siswa yang tidak menngunakan alat peraga. Berdasarkan hasil wawancara menunjukkan bahwa siswa memiliki kemampuan geometri yang baik pada konsep parabola dengan menggunakan alat peraga pada pembelajaran. Selain itu, Sikap siswa terhadap pembelajaran dengan alat peraga adalah positif.
\end{abstract}

\section{INTRODUCTION}

Geometry is a part of mathematics that is very close to our lives. Mathematics is very important because it can facilitate solve problems from simple to complex (Riyadi \& Suprapto, 2013). Volderman states geometry plays an important role in our lives (Kambilombilo \& Sakala, 2015). Geometry is a fundamental method for understanding and explaining the environment, for example measuring length, surface area and volume (Hwang, Su, Huang, \& Dong, 2009).

Geometry is abstract, so for students who have low abstraction ability will feel less interested in the learning process, and find it difficult to understand the concepts of geometry (Kusuma \& Utami, 2017). Sunardi stated that the geometry ability of high school students is still low, and the result of interview with one of the professors of mathematics in Indonesia said that the ability of early semester students geometry is still very concern because in high school level the teacher is 


\section{Journal of Mathematics Science and Education \\ | ISSN (Print) 2623-2375 | ISSN (Online) 2623-2383 | \\ DOI : https://doi.org/10.31540/jmse.v2i1.816 \\ Penerbit : LP4MK STKIP PGRI Lubuklinggau}

less able to explain the geometry material clearly so that it impacts to the lecturer level (Buchori, 2010).

Based on the study of students' logical thinking ability in the course of analytic geometry as a whole it is 59,61 from maximum value 100 (Oktaria, 2017). Ellips, hyperbola, and parabola are subjects in analytical geometry courses that are still difficult to understand by students (Soewardini, 2017). Students tend to use the formula found in solving problems, so they do not have the ability to see the relationship between concepts (Saragih, 2012). Students are still having difficulty in applying the concept especially parabola and hyperbola concept: 1) output difficulty is that students not to remember the analytic geometry formula since the formula of analytic geometry is too long, 2) Visual-Spatial Difficulty include student difficulties in sequencing the steps used to complete analytic geometry because it has difficulty to understand the concepts that exist in the matter (Asmar, 2017).

Geometric objects are abstract and have the potential to create difficulties in learning, so the need for learning media so that students get visual experience to interact with geometry objects (Mahmudi, 2010). Learning media is needed to describe the concept of geometry in real and able to increase learning motivation (Kusuma \& Utami, 2017). One of the learning media is manipulatives.

Manipulatives are important for a student to have a variety of materials to manipulate and explore if students are to develop mathematics understanding (Boggan, Harper, \& Whitmire, 2010). Hedden's research in England, Japan, China, and the United States report the idea that student understanding and mathematics learning will be more effective if manipulatives are used (Schweyer, 2000). Research on the use of the 3D kit serves as a useful instrument in the teaching of multivariable calculus, some of which are (1) geometry orientation of students using the manipulatives did better, (2) the behavior of the 3D kit as a tool (McGee, Jr., Moore-Russo, Ebersole, \& Lomen, D. O.Quintero, 2012).

This study examines the improvement of students' understanding of parabola concepts, the geometric ability of students on the concept of geometry using manipulatives, and student responses to lectures using manipulatives.

\section{METHOD}

This research model is quasi-experiment with pre-test post-test control group design. The experimental class learns the concept of the parabola concept by using manipulatives. The control 
group is learning on it by using traditional model learning. The study design is as follows (Ali, 2014).

$\begin{array}{llr}\text { O1 } & \mathrm{X} & \mathrm{O} 2 \\ -\mathrm{O} 1 & \mathrm{O} 2\end{array}$

Table 1 illustrates the experimental pattern of this research. Table 1 illustrates the experimental pattern of this research.

Tabel 1. Experimental Pattern of The Research

\begin{tabular}{lccc}
\hline Class & $\begin{array}{c}\text { Observation } \\
\text { Premeasurement }\end{array}$ & $\begin{array}{c}\text { Experimental } \\
\text { Process } \\
\text { Premeasurement }\end{array}$ & $\begin{array}{c}\text { Observation } \\
\text { Postmeasurement }\end{array}$ \\
\hline Experimental & Parabola concept & Learning using & Parabola concept \\
& pre-test & manipulatives & Post-test \\
Control & Parabola concept & Learning with a & Parabola concept \\
& pre-test & traditional method & Post-test \\
\hline
\end{tabular}

At this research, the steps are followed in accordance with the quasi-experimental research model. These steps are describing the population, preparing the lesson materials and tools, application steps and collecting the data, analyzing the data and used statistical techniques, findings and discussion.

This research is applied to the first-grade student in the department of mathematics education at one of the universities in Indonesia, who became a mathematics teacher candidate. The population is a student who contracts the analytic geometry course of the academic year 2017/2018. Two classes, which have an academically similar level. Selection of sample by purposive. So that class A is called as the experimental class, class B is called as the control class. Table 2 illustrates the range of students.

Tabel 2. The Range of Students at Experimental and Control Class

\begin{tabular}{ccc}
\hline Group N \% & N & $\%$ \\
\hline Experimental & 32 & 50 \\
Control & 32 & 50 \\
Total & 64 & 100 \\
\hline
\end{tabular}

The whole teaching was conducted by the researcher. The quasi-experimental class was learned with manipulatives materials of the parabola concept, which were prepared by a researcher 


\section{Journal of Mathematics Science and Education \\ | ISSN (Print) 2623-2375 | ISSN (Online) 2623-2383 | \\ DOI : https://doi.org/10.31540/jmse.v2i1.816 \\ Penerbit : LP4MK STKIP PGRI Lubuklinggau}

or taken from sources. The control groups were learned with traditional methods in accordance with lecture their class.

The lesson materials were prepared by using manipulatives. The content of them was constituted of the tutorial questions of a parabola. Here is one of the teaching materials in the lecture.

\subsection{Latus Rectum Parabola}

Lihat alat peraga. Jika titik puncak di $\mathrm{O}(0,0)$, fokus di $(\mathrm{C}, 0)$, dan garis direktris $\mathrm{x}=-\mathrm{a}$, maka buktikan bahwa panjang latus rectum adalah $4 \mathrm{a}$

\section{Figure 1. Parabola Teaching Materials}

At the period of research, the steps, which are mentioned below, were followed: preparing and developing data collecting tools; preparing the manipulatives materials, which are used during the lesson; specifying the experimental and control groups; making pre-post measurements with data collecting tools; pre-test in both classes; application of learning in both classes; post-test on the second grade; and analyzing the data and used statistical techniques

\section{RESULT AND DISCUSSION}

These manipulatives serve to facilitate students in understanding the definitions, determining equations, and understanding information about simple parabola equations. Before it was designed, sketches were made using Geogebra software. This sketch contains simple parabola equation graphs, focus, vertex point, directrix, coordinate axis, and grid. Then this sketch is printed and moved to a wooden board. Plug the small spikes on the sketch (on focus, directrix, and parabola). Complete with the thread that is fastened to the focus and the length is adjusted the furthest distance on the spikes in conics. Here's a picture of parabola manipulatives. 

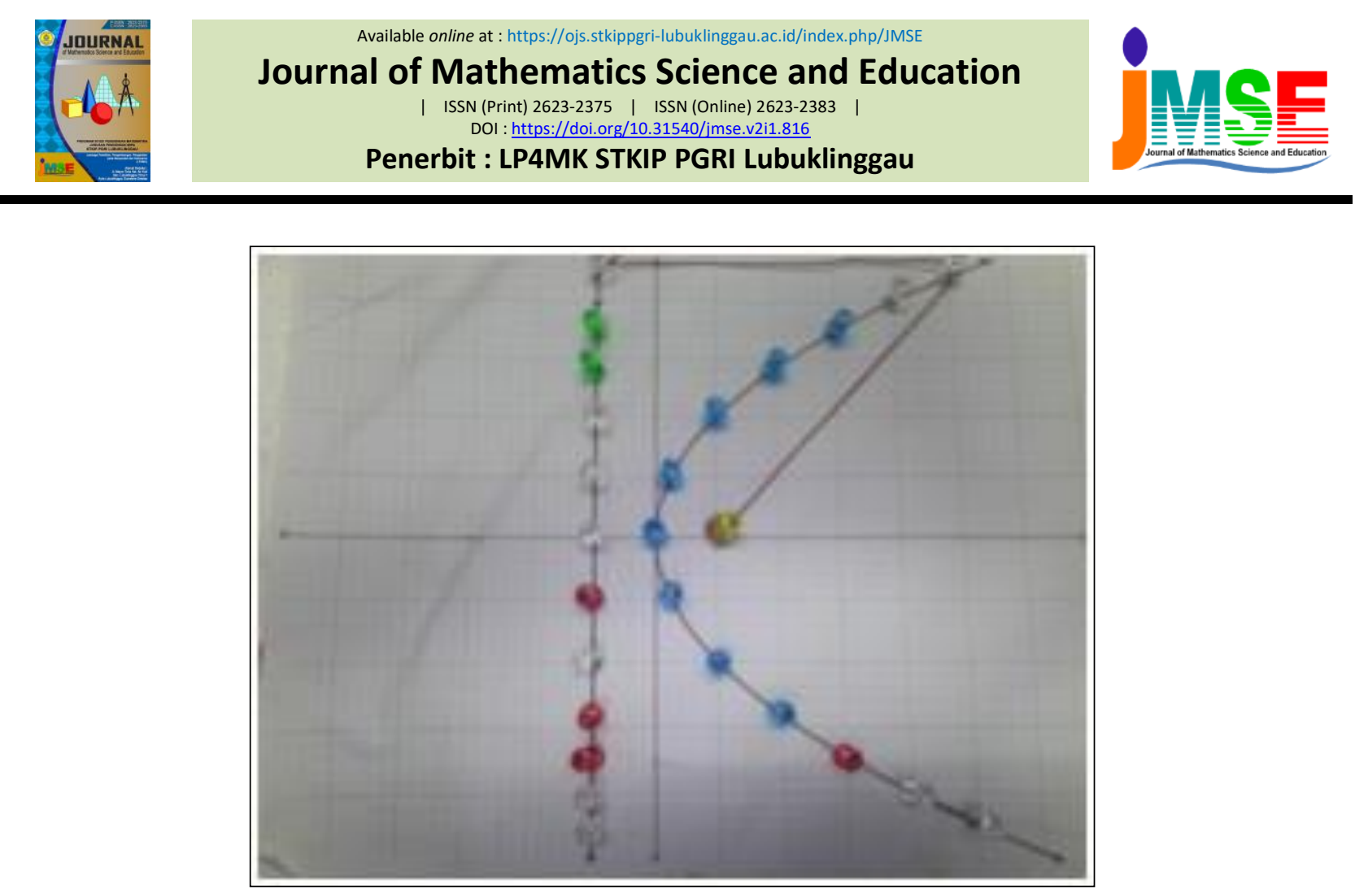

Figure 2. Manipulatives of Parabola

These manipulatives are used by students in analytic geometry courses. Here's the learning environment in the classroom when using manipulatives.

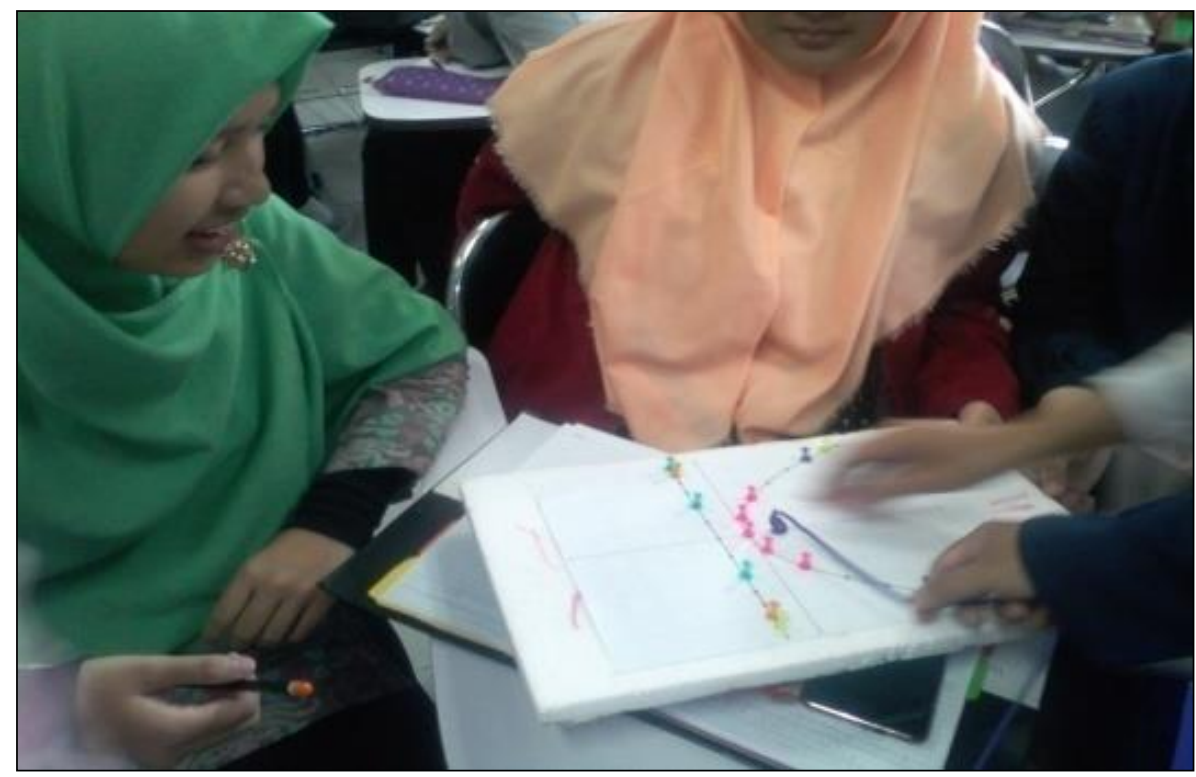

Figure 3. Learning Situation in Classroom

How to use manipulatives in showing the definition of a parabola. Wrap one end of the yarn at the focus, then wrap it around the spikes on the parabola. Then wrap it back perpendicular to the spikes on the directrix. Repeat the same way but through another spike on the parabola and the directional. This demonstration shows that the distance from the points at the focus and the director are fixed. The demonstration is shown in figure 4. 


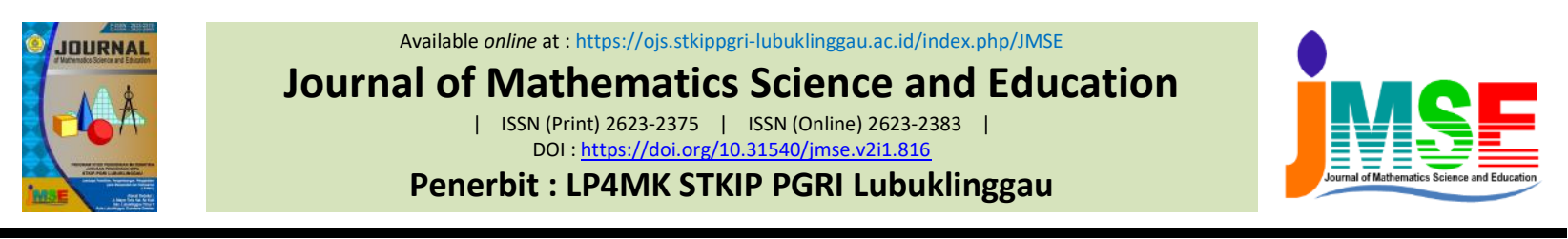

Based on this demonstration, students are expected to find the definition of a parabola. The definition of a parabola is the place of the points where the point distance to the point of focus is equal to that point distance to the directrix. So the ratio of point distance to the point of focus with the point distance to the directrix is one $(\mathrm{e}=1)$. Simple parabola vertex point equation through point $\mathrm{O}(0,0)$. Through manipulatives, it is expected that students can determine simple parabola equations. By choosing the focus $F(c, 0)$ and directrix $x=-a$. And the student performing $P(x, y)$ is any point that satisfies the properties $|\mathrm{FP}|=\mathrm{DP} \mid$ with $\mathrm{D}$ is the projection of $\mathrm{P}$ on the directrix. Furthermore, the equation is derived in the following way.

$$
\begin{aligned}
& |F P|=|P D| \\
& \leftrightarrow \sqrt{(x-a)^{2}+(y-0)^{2}}=\frac{|x-a|}{\sqrt{1^{2}+0^{2}}} \\
& \leftrightarrow(x-a)^{2}+(y-0)^{2}=\left(\frac{|x-a|}{\sqrt{1^{2}+0^{2}}}\right)^{2} \\
& \leftrightarrow x^{2}-2 a x+a^{2}+y^{2}=x^{2}-2 a x+a^{2} \\
& \leftrightarrow y^{2}=4 a x
\end{aligned}
$$

So a simple parabola equation is $\mathrm{y}^{2}=4 \mathrm{ax}$.

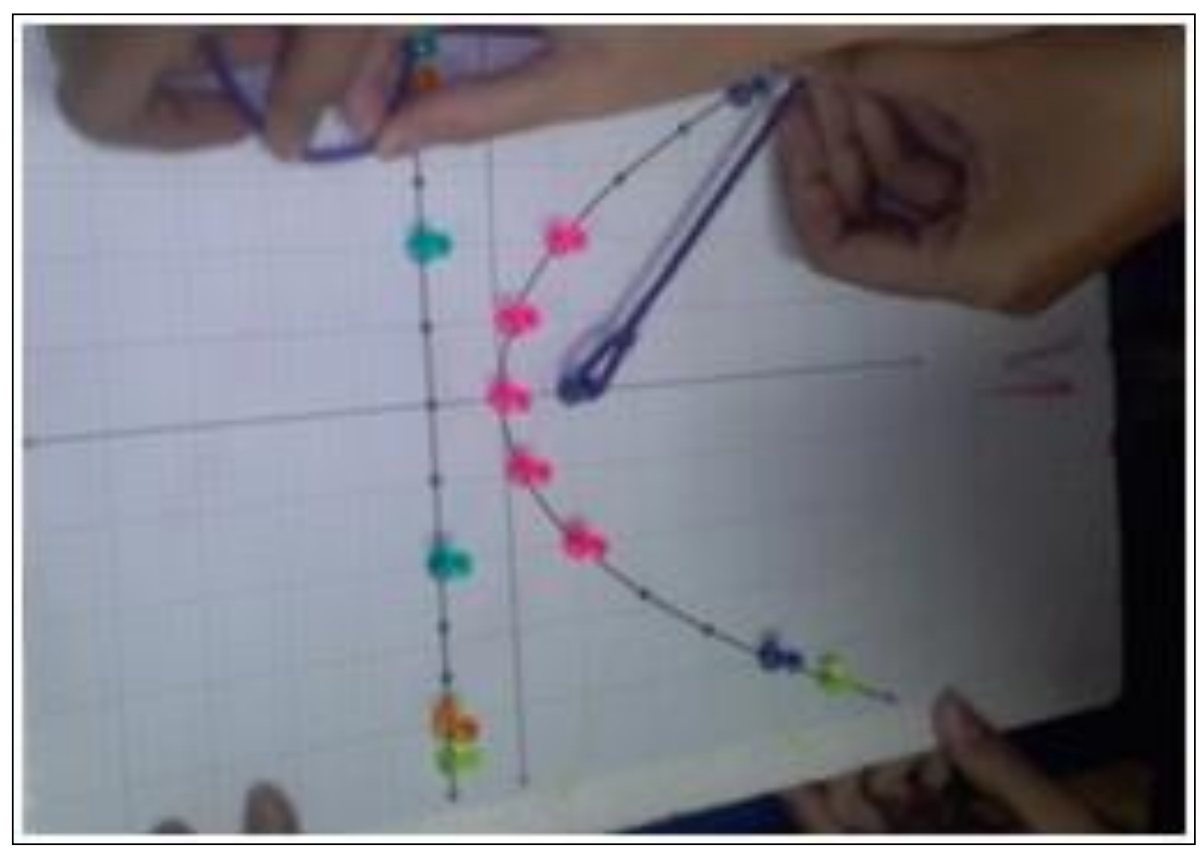

Figure 4. Parabola Definition 


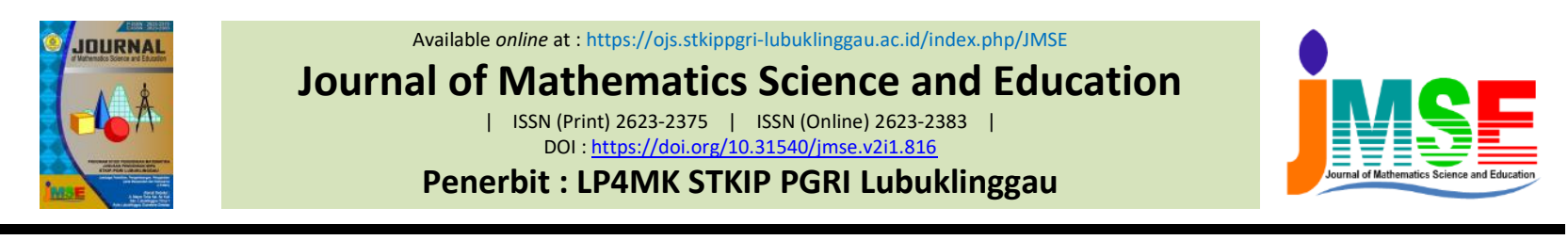

Students then use manipulatives to explain information about simple parabola equations:

a. The parabola is symmetrical to the line through the focus and perpendicular to the director. The line is a parabola axis.

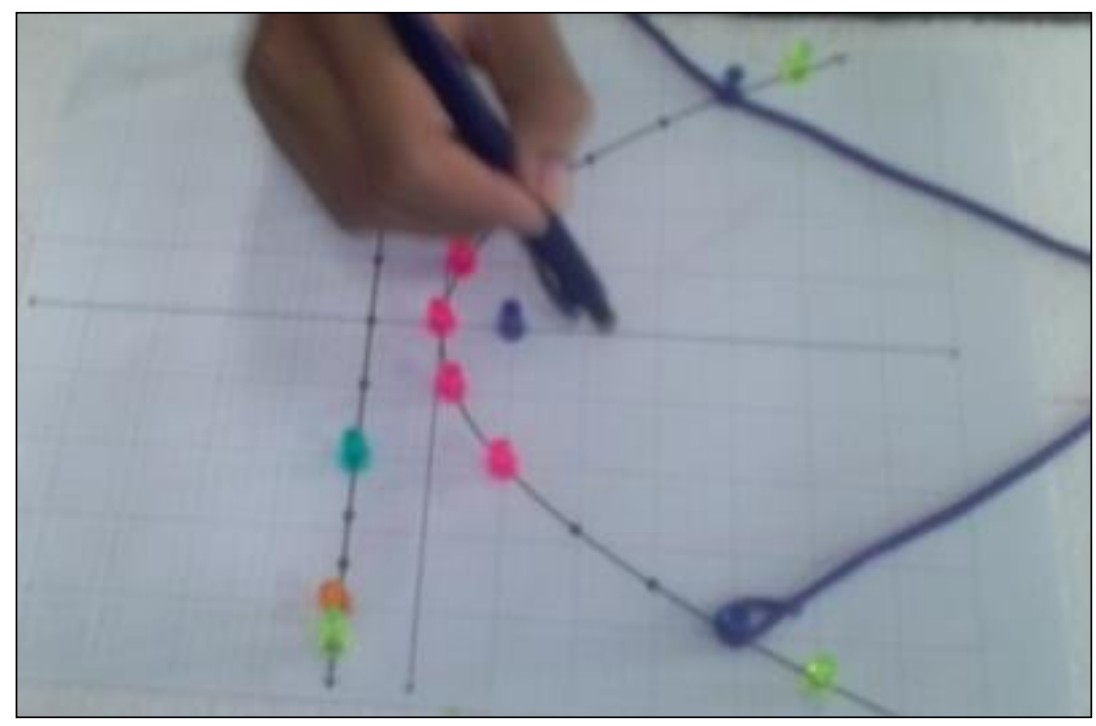

Figure 5. Parabola Axis

b. The vertex point at.

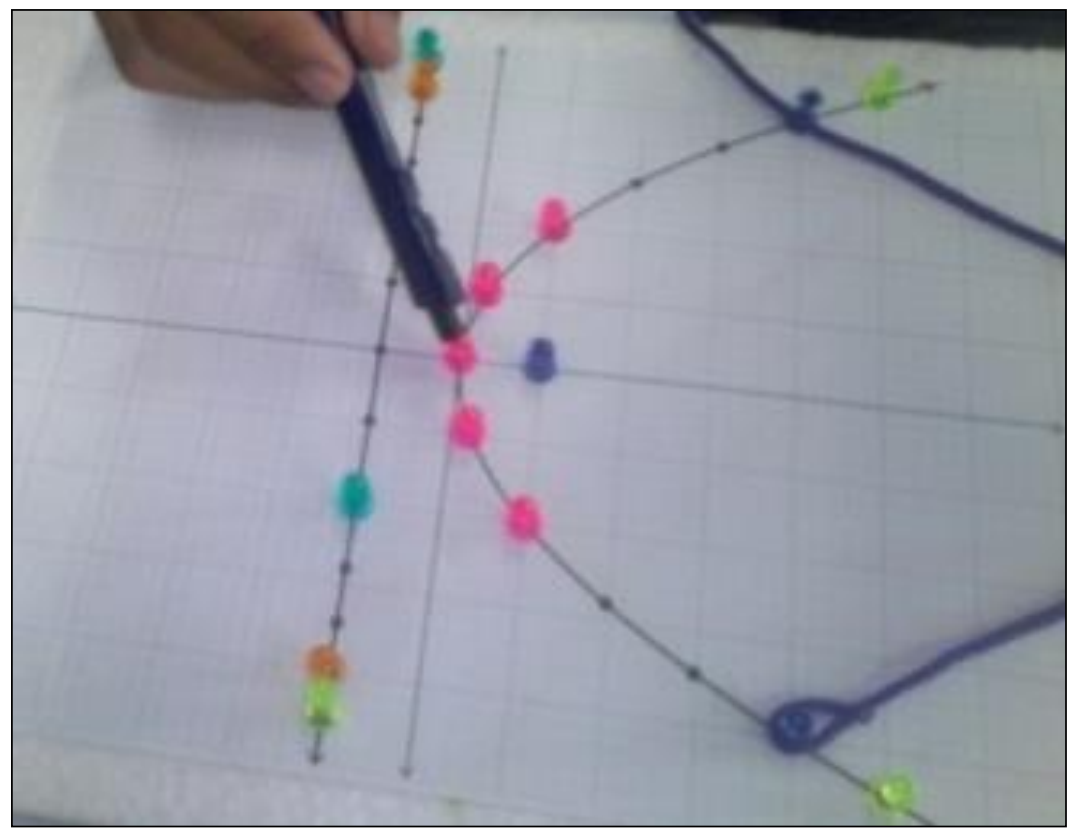

Figure 6. Vertex Point of Parabola 


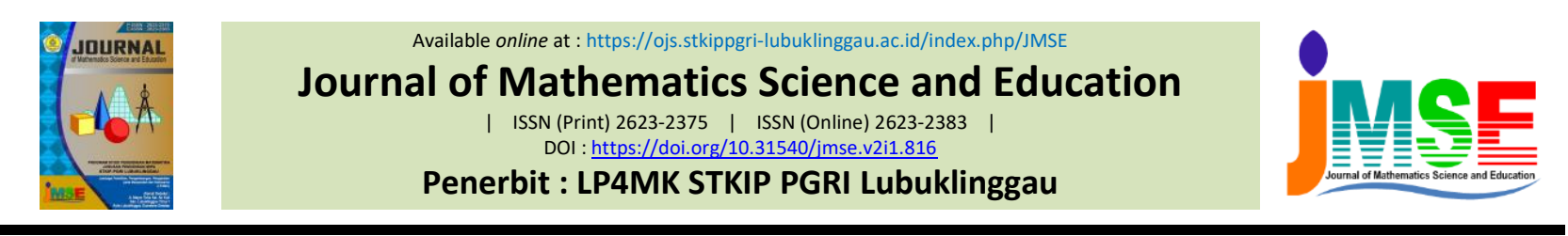

c. Chords that go through focus are called focus chords. If the chords are perpendicular to the parabola axis then it is called latus rectum parabola.

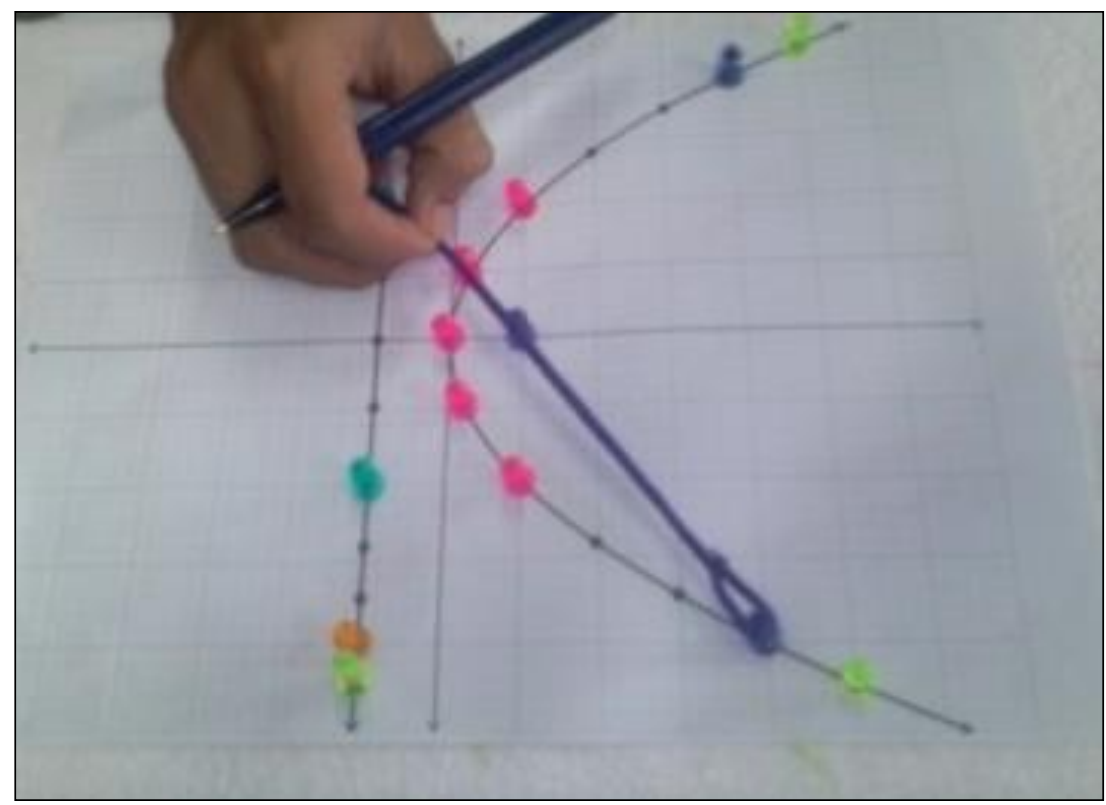

Figure 7. Focus Chords

d. The distance of the focus point on the directrix is $2 \mathrm{a}$. So the length of the latus rectum is $4 \mathrm{a}$. Latus rectum is useful when drawing a parabola because it can determine two points on the curve. If the equation is written in one simple form $\mathrm{y}^{2}= \pm 4 \mathrm{ax}$ or $\mathrm{x}^{2}= \pm 4$ ay then the absolute value of the linear coefficient is the length of the latus rectum.

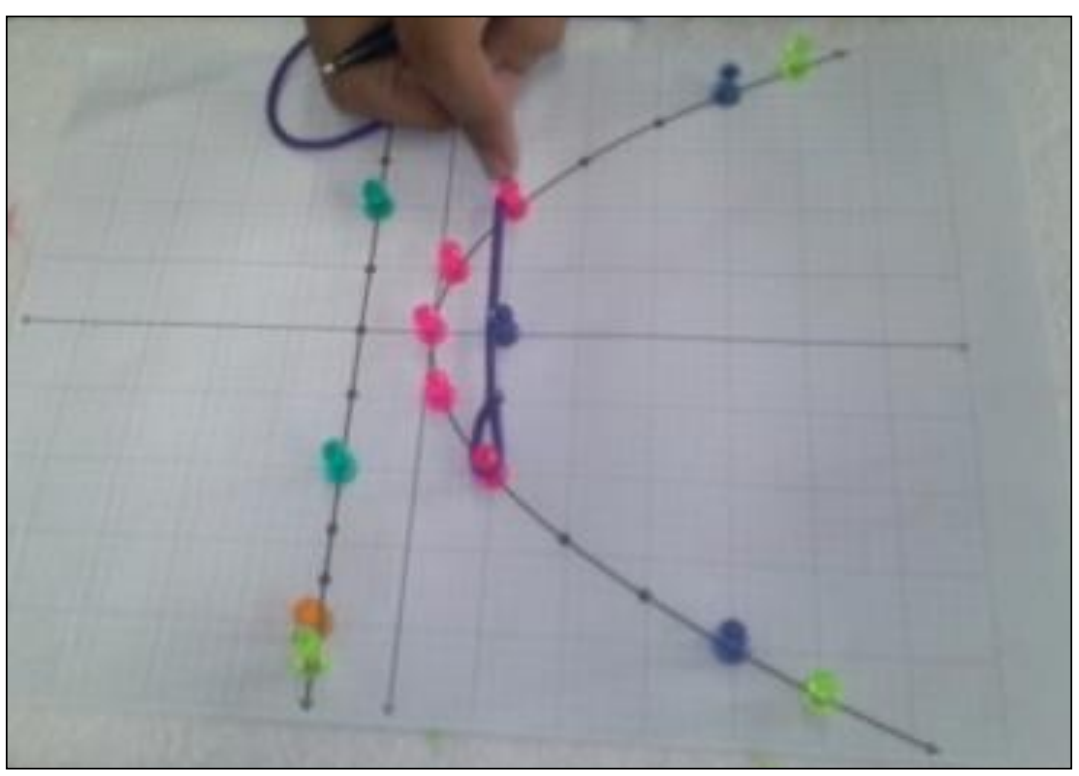

Figure 8. Latus Rectum 


\section{Journal of Mathematics Science and Education \\ | ISSN (Print) 2623-2375 | ISSN (Online) 2623-2383 | \\ DOI : https://doi.org/10.31540/jmse.v2i1.816 \\ Penerbit : LP4MK STKIP PGRI Lubuklinggau}

Analysis of the findings on research in the form of test data, interview data, and the results of questionnaires. Before the students' learning begins pre-test the concept of a parabola. The following is descriptive data of the pre-test score.

Table 3. Pretest Descriptive Data

\begin{tabular}{cccccc}
\hline & Code & N & Mean & $\begin{array}{c}\text { Std. } \\
\text { Deviation }\end{array}$ & $\begin{array}{c}\text { Std. Error } \\
\text { Mean }\end{array}$ \\
\hline \multirow{2}{*}{ Class } & Control & 32 & 2,50 & 2,84 & 0,50 \\
& Experimental & 32 & 1,17 & 4,88 & 0,86 \\
\hline
\end{tabular}

Descriptively in table 3, the average pretest is different. So the average equality test is done in both classes. But previously done the first test of normality in table 4 .

Tabel 4. Test the Normality of Pretest Data

\begin{tabular}{lcccc}
\hline & Code & \multicolumn{3}{c}{ Shapiro-Wilk } \\
& & Statistic & df & Sig. \\
\hline \multirow{2}{*}{ Class } & Control & 0,71 & 32 & 0,00 \\
& Experimental & 0,26 & 32 & 0,00 \\
\hline
\end{tabular}

In table 4 it can be seen that the control class and the experimental class are from the not normally distributed population. Thus, the average equality test of the students' initial ability in parabola concepts using the Mann-Whitney test (Ruseffendi, 1993).

Tabel 5. Non-Parametric Test of Pretest Data

\begin{tabular}{|c|c|c|c|}
\hline Null Hypothesis & Test & Sig. & Decision \\
\hline $\begin{array}{l}\text { The distribution of Control } \\
\text { and experiment class is the } \\
\text { same across categories }\end{array}$ & $\begin{array}{l}\text { Independent- } \\
\text { Samples Mann- } \\
\text { Whitney U Test }\end{array}$ & 0,001 & $\begin{array}{l}\text { Reject the null } \\
\text { hypothesis }\end{array}$ \\
\hline
\end{tabular}

Based on table 5 the significance value is less than 0.05 . This means that students' initial ability to parabola concepts differs significantly. The following descriptive data of the posttest score on both classes are presented.

Table 6. Postest Descriptive Data

\begin{tabular}{llcccc}
\hline \multicolumn{1}{c}{ Code } & N & Mean & $\begin{array}{c}\text { Std. } \\
\text { Deviation }\end{array}$ & $\begin{array}{c}\text { Std. Error } \\
\text { Mean }\end{array}$ \\
\hline \multirow{2}{*}{ Class } & Control & 32 & 65,16 & 29,44 & 5,21 \\
& Experimental & 32 & 80,66 & 21,91 & 3,87 \\
\hline
\end{tabular}




\section{Journal of Mathematics Science and Education \\ ISSN (Print) 2623-2375 | ISSN (Online) 2623-2383 | \\ DOI : https://doi.org/10.31540/jmse.v2i1.816 \\ Penerbit : LP4MK STKIP PGRI Lubuklinggau}

Descriptively the posttest grade of the experimental class is higher than the control class. However, because students 'initial ability differs significantly, so as to know students' understanding improvement using normalized gain data. The normalized gain calculation according to Meltzer (Sudihartinih, 2014) follows:

$$
\text { Normalized Gain }(\mathrm{g})=\frac{\text { postest } \text { score }- \text { pretest } \text { score }}{\text { ideal score }- \text { pretest score }}
$$

The descriptive data from the normalized gain data of the control class and the experimental class are in Table 7.

Table 7. Normalized gain descriptive data

\begin{tabular}{cccccc}
\hline & Code & N & Mean & $\begin{array}{c}\text { Std. } \\
\text { Deviation }\end{array}$ & $\begin{array}{c}\text { Std. Error } \\
\text { Mean }\end{array}$ \\
\hline \multirow{2}{*}{ Class } & Control & 32 & 0,64 & 0,30 & 0,06 \\
& Experimental & 32 & 0,81 & 0,22 & 0,04 \\
\hline
\end{tabular}

Descriptively the normalized gain in the two classes appears to be different. So the average difference test is done. But before the normality test that is in table 8 .

Table 8. Normalized Gain Descriptive Data

\begin{tabular}{lclll}
\hline & Code & \multicolumn{3}{c}{ Shapiro-Wilk } \\
& & Statistic & df & Sig. \\
\hline \multirow{2}{*}{ Class } & Control & 0,92 & 32 & 0,017 \\
& Experimental & 0,84 & 32 & 0,000 \\
\hline
\end{tabular}

Table 8 shows that the experimental class comes from a population that is not normally distributed. So test the average difference in both classes using the Mann-Whitney test (Ruseffendi, 1993). Here the results of uni Mann-Whitney are listed in table 9.

Tabel 9. Non-Parametric Test of Normalized Gain Data

\begin{tabular}{|c|c|c|c|}
\hline Null Hypothesis & Test & Sig. & Decision \\
\hline $\begin{array}{l}\text { The distribution of } \\
\text { control and experiment } \\
\text { class is the same across } \\
\text { categories }\end{array}$ & $\begin{array}{l}\text { Independent- } \\
\text { Samples Mann- } \\
\text { Whitney U Test }\end{array}$ & 0,013 & $\begin{array}{l}\text { Reject the null } \\
\text { hypothesis }\end{array}$ \\
\hline
\end{tabular}

Based on table 9 it can be seen that the significance value is less than 0.05 . This means that students' understanding of parabola concepts in the two classes differ significantly. 


\section{Journal of Mathematics Science and Education \\ | ISSN (Print) 2623-2375 | ISSN (Online) 2623-2383 | \\ DOI : https://doi.org/10.31540/imse.v2i1.816 \\ Penerbit : LP4MK STKIP PGRI Lubuklinggau}

To evaluate the thought processes of students using the manipulatives, samples of students from the experimental and control class were interviewed. The control sample consisted of two students with the highest grade and two students with the lowest grade, the students were randomly selected from the control class. The experimental sample also consisted of two students with the highest score and two students with the lowest score selected at the random from the experimental class to meet the grade criteria. The interview consisted of two questions. For each question, there was a predetermined set of hints that could be offered, if needed, at various stages of each problem in the interview. The results are in table 10.

Table 10. Interview Question Results for Control and Treatment Samples on Questions on Parabola Definitions

\begin{tabular}{|c|c|c|c|c|}
\hline \multirow[b]{2}{*}{ Demonstration } & \multicolumn{2}{|c|}{ Control class } & \multicolumn{2}{|c|}{ Experimental class } \\
\hline & $\begin{array}{l}\text { Higest grade } \\
\text { (Number) }\end{array}$ & $\begin{array}{c}\text { Lowest grade } \\
\text { (Number) }\end{array}$ & $\begin{array}{l}\text { Higest grade } \\
\text { (Number) }\end{array}$ & $\begin{array}{c}\text { Lowest grade } \\
\text { (Number) }\end{array}$ \\
\hline $\begin{array}{l}\text { Describe the definition of a } \\
\text { parabola with manipulatives } \\
\text { without help }\end{array}$ & 2 & 1 & 2 & 2 \\
\hline $\begin{array}{l}\text { Describe the definition of a } \\
\text { parabola with manipulatives } \\
\text { with help }\end{array}$ & 0 & 0 & 0 & 0 \\
\hline $\begin{array}{l}\text { Can not explain the definition } \\
\text { of a parabola with } \\
\text { manipulatives }\end{array}$ & 0 & 1 & 0 & 0 \\
\hline
\end{tabular}

In the first interview, students were asked to explain the definition of a parabola using manipulatives. The interview results showed In the experimental class all students can explain it without help. However, in the control class, one of the students (the lowest score) can not explain the definition of a parabola by using manipulatives.

Table 11. Interview Question Results for Control and Treatment Samples on Questions about Parabola Explanations

\begin{tabular}{lcccc}
\hline \multicolumn{1}{c}{ Demonstration } & $\begin{array}{c}\text { Control class } \\
\text { Higest grade } \\
\text { (Number) }\end{array}$ & $\begin{array}{c}\text { Lowest grade } \\
\text { (Number) }\end{array}$ & $\begin{array}{c}\text { Experimental class } \\
\text { Higest grade } \\
\text { (Number) }\end{array}$ & $\begin{array}{c}\text { Lowest grade } \\
\text { (Number) }\end{array}$ \\
\hline $\begin{array}{l}\text { Explaining parabola } \\
\text { information with } \\
\text { manipulatives without help }\end{array}$ & 1 & 0 & 2 & 2 \\
$\begin{array}{l}\text { Explain parabola information } \\
\text { with manipulatives with help }\end{array}$ & 1 & 2 & 0 & 0 \\
$\begin{array}{l}\text { Can not explain parabola } \\
\text { information with } \\
\text { manipulatives }\end{array}$ & 0 & 0 & 0 & 0 \\
\hline
\end{tabular}




\section{Journal of Mathematics Science and Education \\ | ISSN (Print) 2623-2375 | ISSN (Online) 2623-2383 | \\ DOI : https://doi.org/10.31540/imse.v2i1.816 \\ Penerbit : LP4MK STKIP PGRI Lubuklinggau}

In the second interview, the students were asked to explain the parabola description. The information about the parabola is as follows:

1. The parabola is symmetrical to the line through the focus and perpendicular to the directrix line. The line is a parabola axis.

2. The focus distance to the directional line is $2 \mathrm{a}$.

3. Vertex point at $\mathrm{V}(0,0)$.

4. Chords that go through the focus are called focus chords. If the chords are perpendicular to the parabola axis then it is called latus rectum parabola. The length of the rectum latus is $4 \mathrm{a}$.

Based on the results of the interviews it is known that all students in the experimental class can explain the parabola without help. As for the control class, one student can explain parabola information without help, and three others with help. In addition, one student with the lowest grade in the control class incorrectly mentions the definition of latus rectum.

To know students' attitudes toward manipulatives in lecturing, we give questionnaires to students. As for the content of the statement, 'manipulatives used in lectures help in understanding the concept of conic. Here the results of the response student on Table 12.

Table 12. Questionnaire Results Confirm Students Deem Manipulatives in Understanding Geometry of Parabola Concepts

\begin{tabular}{cccc}
\hline Strongly agree (\%) & Agree (\%) & Disagree (\%) & Strongly disagree (\%) \\
\hline 59 & 38 & 3 & 0 \\
\hline
\end{tabular}

To know students' attitudes toward manipulatives in lecturing, we give questionnaires to students. As for the content of the statement, 'manipulatives used in lectures help me in understanding the concept of conic. Here the results of student responses are table 12.

- It can explain the concept, but not effective.

- Not enjoy.

The following are some positive comments from students.

- Fun, easy to understand the concept

- The manipulatives are right, so I understand

Furthermore, the students' comments are grouped into positive and negative comments. The result of data analysis showed that a negative impression was $6 \%$ of the number of students and 94\% gave a positive impression. 


\section{CONCLUSION}

To measure the increased understanding of parabola concepts, pre-tests and post-tests were conducted in both classes. The result of normalized gain data analysis shows that the improvement of students' understanding in the class that uses the manipulatives is higher than the class that does not use manipulatives. These results are in accordance with previous research studies (Boggan et al., 2010; Schweyer, 2000; Sudihartinih \& Purniati, 2017). Furthermore, interviews were used to determine students' geometry abilities, and the students obtained good geometry skills in parabola concepts using student manipulatives, in accordance with McGee's et al findingset (McGee et al., 2012). The result of positive student response to lectures using manipulatives is the correspondence to the Ruseffendi (Ruseffendi, 1991) which states that positive attitudes toward mathematics can be positively correlated with learning achievement. So manipulatives are very well used in learning. The manipulatives we have designed are in Sudihartinih and Purniati (Purniati \& Sudihartinih, 2015; Sudihartinih \& Purniati, 2016, 2017, 2018).

\section{REFERENCES}

Ali, M. (2014). (2014). RISET KUANTITATIF (Metodologi dan Aplikasinya). Makalah pada Pelatihan Pembimbing Skripsi di Universitas Pendidikan Indonesia pada Tanggal 3 Desember 2014.

Asmar, A. (2017). PROSIDING:Analysis of Student Difficulties In Solving Problems of Analytical Geometryin Parabolic And Hiperbolic Materials. In Science And Technology.

Boggan, M., Harper, S., \& Whitmire, A. (2010). Using manipulatives to teach elementary mathematics. Journal of Instructional Pedagogies, 3(1), 1-10. Retrieved from http://www.aabri.com/manuscripts/10451.pdf

Buchori, A. (2010). Potensi Program Cabri 3D Untuk Mendukung Pembelajaran. IKIP PGRI Semarang, (024), 1-11.

Hwang, W. Y., Su, J. H., Huang, Y. M., \& Dong, J. J. (2009). A study of multi-representation of geometry problem solving with Virtual Manipulatives and Whiteboard system. Educational Technology and Society, 12(3), 229-247.

Kambilombilo, D., \& Sakala, W. (2015). An Investigation into the Challenges In-Service Student Teachers Encounter in Transformational Geometry, "Reflection and Rotation". The Case of Mufulira College of Education. Journal of Education and Practice, 6(2), 139-149. Retrieved from http://search.ebscohost.com/login.aspx?direct=true $\& d b=$ eric $\& A N=E J 1083792 \&$ site=ehostlive

Kusuma, A. B., \& Utami, A. (2017). Penggunaan Program Geogebra dan Casyopee dalam Pembelajaran Geometri Ditinjau dari Motivasi Belajar Siswa. Jurnal Mercumatika, 1(2).

Mahmudi, A. (2010). Membelajarkan Geometri dengan Program GeoGebra. Prosiding Seminar Nasional Matematika Dan Pendidikan Matematika, (November), 469-477. 


\section{Journal of Mathematics Science and Education \\ | ISSN (Print) 2623-2375 | ISSN (Online) 2623-2383 | \\ DOI : https://doi.org/10.31540/imse.v2i1.816 \\ Penerbit : LP4MK STKIP PGRI Lubuklinggau}

McGee, D., Jr., Moore-Russo, D., Ebersole, D., \& Lomen, D. O.Quintero, M. M. (2012). Visualizing Three-Dimensional Calculus Concepts: The Study of a Manipulative's Effectiveness. PRIMUS, 22(4), 265-283.

Oktaria, D. (2017). Kemampuan Berpikir Logis Mahasiswa Pendidikan Matematika Universitas PGRI Palembang pada Mata Kuliah Geometri Analitik.

Purniati, T., \& Sudihartinih, E. (2015). Visual Aids in Analytical Geometry Course in Conic Concept. Prosiding Pada Seminar Internasional MSCEIS Di Bandung.

Riyadi, S., \& Suprapto, N. (2013). Studi Korelasi Penalaran Konsep Fisika Dan Penalaran Matematika Terhadap Hasil Belajar Siswa Di Sman 15 Surabaya Pada Pokok Bahasan Gerak Parabola. Inovasi Pendidikan Fisika, 2(3), 75-79.

Ruseffendi, E. T. (1991). Penilaian Pendidikan dan Hasil Belajar Siswa Khususnya dalam Pengajaran Matematika. Bandung. Bandung: Alfabeta.

Ruseffendi, E. T. (1993). Statistika Dasar untuk Penelitian Pendidikan. Jakarta: Depdikbud.

Saragih, S. (2012). Application of Generative Learning In Coorperative Settings Tps Type On Learning Areas And Space Analitic Geometery. Jurnal Pendidikan Matematika PARADIKMA, 6(1), 27-48.

Schweyer, S. R. (2000). Effective Use of Manipulatives. (as seen in CORE PLUS). Retrieved from http://gphillymath.org/ExempPaper/Documents/manipulatives.pdf

Soewardini, H. M. D. (2017). Deskripsi Asimilasi Dan Akomodasi Mahasiswa Berkemampuan Sedang Dalam Belajar Ellips, Hiperbola, Dan Parabola. Gammath: Jurnal Ilmiah Program Studi Pendidikan Matematika, 1(1), 32-37.

Sudihartinih, E. (2014). Meningkatkan Pemahaman Matematik Mahasiswa melalui Pembelajaran Kooperatif dengan Metode Pemberian Tugas Terstruktur dalam Perkuliahan Matematika Dasar. Prosiding Pada Seminar Nasional Matematika Di UNPAR Bandung Vol. 9.

Sudihartinih, E., \& Purniati, T. (2016). ALAT PERAGA IRISAN KERUCUT. Prosiding Pada Seminar Nasional Matematika Di UNPAR Bandung Vol. 11.

Sudihartinih, E., \& Purniati, T. (2017). Meningkatkan Kemampuan Pemahaman Matematis Mahasiswa dalam Perkuliahan Geometri Analitik pada Konsep Irisan Kerucut dengan Menggunakan Alat Peraga. Prosiding Pada Seminar Nasional Matematika Di UNPAR Bandung Vol 12.

Sudihartinih, E., \& Purniati, T. (2018). Manipulative's of Function Translation. IOP Conference Series: Materials Science and Engineering, 288(1). https://doi.org/10.1088/1757$899 X / 288 / 1 / 012063$ 